\title{
Article \\ Genome-Wide SNPs Detect Hybridisation of Marsupial Gliders (Petaurus breviceps breviceps $\times$ Petaurus norfolcensis) in the Wild
}

\author{
Monica L. Knipler ${ }^{1} \mathbb{D}$, Mark Dowton ${ }^{2}$ and Katarina Maryann Mikac ${ }^{1, *(\mathbb{D})}$ \\ 1 Faculty of Science, Medicine and Health, School of Earth, Atmospheric and Life Sciences, University of \\ Wollongong, Wollongong, NSW 2522, Australia; mk972@uowmail.edu.au \\ 2 Faculty of Science, Medicine and Health, The School of Chemistry and Molecular Bioscience, University of \\ Wollongong, Wollongong, NSW 2522, Australia; mdowton@uow.edu.au \\ * Correspondence: kmikac@uow.edu.au
}

check for updates

Citation: Knipler, M.L.; Dowton, M.; Mikac, K.M. Genome-Wide SNPs Detect Hybridisation of Marsupial Gliders (Petaurus breviceps breviceps $\times$ Petaurus norfolcensis) in the Wild. Genes 2021, 12, 1327. https:// doi.org/10.3390/genes12091327

Academic Editor: Stephanie McKay

Received: 11 August 2021

Accepted: 25 August 2021

Published: 27 August 2021

Publisher's Note: MDPI stays neutral with regard to jurisdictional claims in published maps and institutional affiliations.

Copyright: (c) 2021 by the authors. Licensee MDPI, Basel, Switzerland. This article is an open access article distributed under the terms and conditions of the Creative Commons Attribution (CC BY) license (https:// creativecommons.org/licenses/by/ $4.0 /)$.

\begin{abstract}
Petaurus breviceps and Petaurus norfolcensis have produced hybrids in captivity, however there are no reported cases of Petaurus hybridisation in the wild. This study uses morphological data, mitochondrial DNA, and nuclear genome-wide SNP markers to confirm P. breviceps breviceps $\times$ P. norfolcensis hybridisation within their natural range on the central coast of New South Wales, Australia. Morphological data identified a potential hybrid that was confirmed with next-generation sequencing technology and 10,111 genome-wide SNPs. Both STRUCTURE and NewHybrid analyses identified the hybrid as a P. norfolcensis backcross, which suggests an initial F1 hybrid was fertile. The mitochondrial DNA matched that of a $P$. $b$. breviceps, indicating that a $P . b$. breviceps female initially mated with a $P$. norfolcensis male to produce a fertile female offspring. Our study is an important example of how genome-wide SNPs can be used to identify hybrids where the distribution of congeners overlaps. Hybridisation between congeners is likely to become more frequent as climate changes and habitats fragment, resulting in increased interactions and competition for resources and mates.
\end{abstract}

Keywords: DArTseq; hybridisation; Petaurus; SNPs; genomics; conservation; habitat fragmentation

\section{Introduction}

There are documented cases of Australian mammal hybridisation in captivity where parental pairings are known, but there is limited evidence of it occurring in the wild [1-3]. Mammal hybridisation was historically thought to be a rare occurrence in the wild, however, this perspective has started to shift as advances in next-generation sequencing technology provide fresh insights through genomics [4-6]. Genome-wide single nucleotide polymorphisms (SNPs) have successfully detected hybrids in wild populations of canids [7], and has also been used to detect hybridisation in other vertebrates such as Australian frogs [8]. Identifying hybrid zones is important for wildlife conservation, as hybrids are typically less fit than their parents due to outbreeding of genes from two species [9,10]. Additionally, not all hybrids reach maturity and those that do can be infertile [11]. This can be detrimental in small populations where infertile hybrids can take away resources and mates from a threatened species.

Habitat destruction and fragmentation are known to increase species interactions, which can, in turn, increase the chances of hybridisation [12]. Australia has experienced extremely high levels of deforestation, and species that share distributions are encountering each other more frequently in fragmented patches, leading to increased competition for resources [13]. The genus Petaurus consists of small, marsupial gliders that are particularly susceptible to habitat loss due to their arboreal nature $[14,15]$. Two Petaurus species that share the same distribution are $P$. norfolcensis and $P$. breviceps. Both species occur along 
the east coast of Australia, with P. norfolcensis sharing habitats in Queensland with $P . b$. longicaudus and P. b. breviceps, and the rest of its range with P. b. breviceps (Figure 1) $[15,16]$. P. norfolcensis is currently listed as a threatened species in South Australia, Victoria, and New South Wales, and common in Queensland (National Parks and Wildlife Act 1972, Flora and Fauna Guarantee Act 1988, Threatened Species Conservation Act 1995), while $P$. breviceps is listed as common across each state. The conservation status and listing of $P$. breviceps may change with the recent confirmation of the three species, where only P. breviceps was once recognised [15].

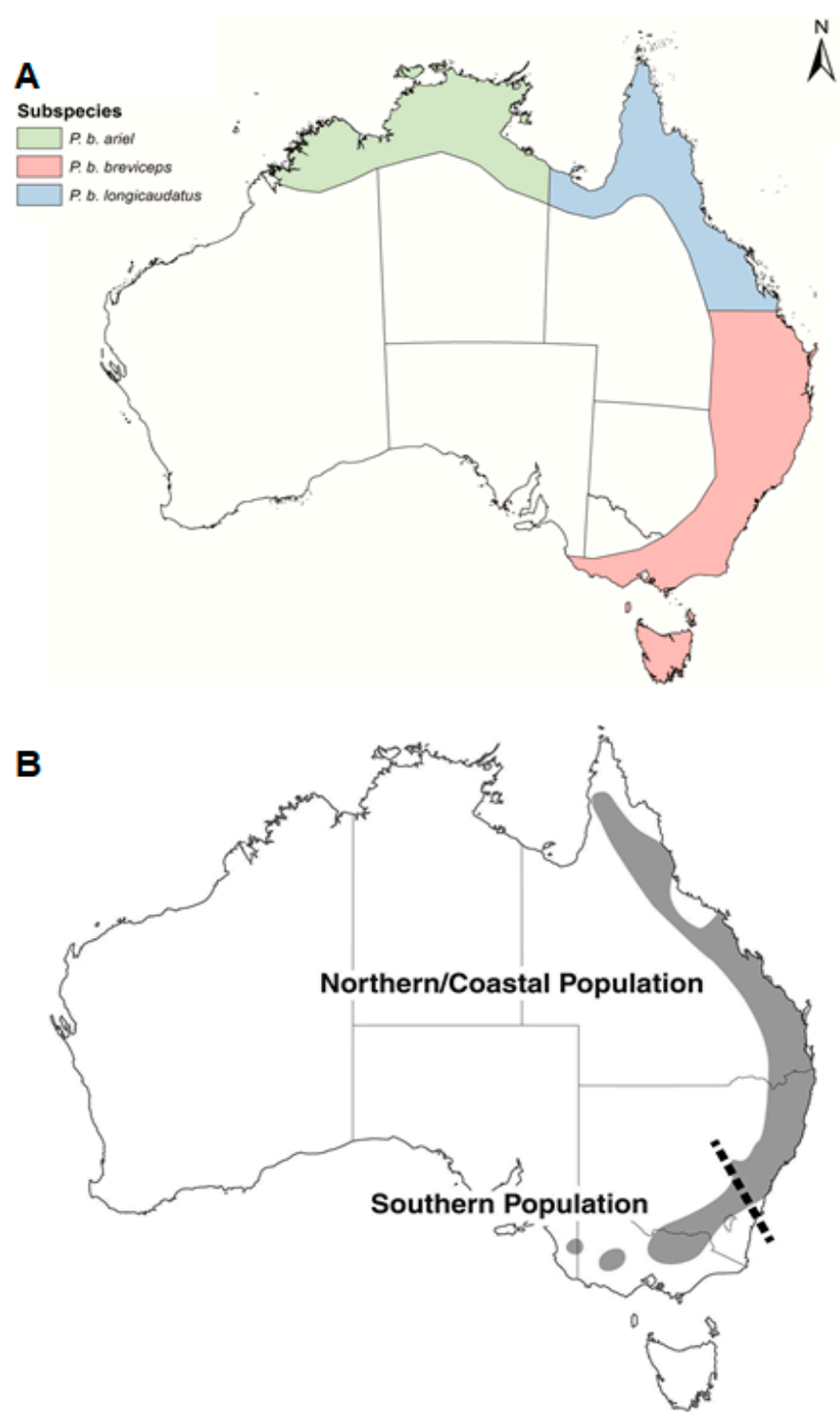

Figure 1. (A) P. breviceps subspecies distribution within Australia. Figure taken from Cremona et al. [15]; (B) P. norfolcensis distribution within Australia. Areas either side of the dashed line represent two genetically distinct populations. Figure taken from Crane et al. [16].

P. breviceps and P. norfolcensis are believed to have diverged into separate species at least 4.46 million years ago based on fossil evidence by Malekian et al. [17]. They are both morphologically similar to each other with a few distinguishing features. Notably, P. norfolcensis weighs significantly more than $P$. breviceps (190-330 g, 90-150 g, respectively) [18-20]. $P$. norfolcensis have thick, long tails that are exclusively black while $P$. breviceps can have a white-tip on their tail. The head length is longer in P. norfolcensis than P. breviceps, as P. breviceps has a round head and snub nose $[18,20]$. 
Despite the overlap in distribution across Australia, there are currently no known cases of $P$. breviceps and $P$. norfolcensis hybridisation in the wild. Interbreeding of $P$. breviceps and $P$. norfolcensis is possible given the two records of hybridisation in captivity reported by Fleay [2] and Zuckerman [3]. Smith [21] attempted to replicate this by interbreeding $P$. breviceps and P. norfolcensis in captivity in 1964, but all attempts were unsuccessful. Reproduction in P. breviceps and P. norfolcensis occurs year round with no separation of breeding seasons [22], increasing the potential of congener mating. Additionally, both species feed on similar sap, pollen, nectar, and invertebrate species $[20,23,24]$. This means that $P$. breviceps and P. norfolcensis can seek to occupy the same habitat fragment, especially if habitat fragmentation imposes pressure on interspecies competition.

We examined a region of eastern Australia where $P$. $b$. breviceps and $P$. norfolcensis are known to coexist in the wild. Morphological data, mitochondrial DNA (mtDNA), and nuclear data in the form of genome-wide SNPs are used to identify pure P. b. breviceps, pure $P$. norfolcensis, and potential hybrids.

\section{Materials and Methods}

\subsection{Genetic Sampling and Morphological Measurements}

This study used genomic DNA collected from 21 locations within the Hunter region of NSW, seven of which only trapped $P$. b. breviceps, nine only trapped $P$. norfolcensis, while five found both species coexisting, and both species were live trapped (Figure 2). Trapping methodology and sampling sites were those of Knipler et al. [25]. Morphological data assisted with the assignment of individuals to either P. b. breviceps or P. norfolcensis. Measurements included head width, head length, body weight, right hind foot length, tail length, sex, reproductive status, and tail tip colour. During the trapping period, DNA was collected from Petaurus individuals using a sterilised $2 \mathrm{~mm}$ ear punch and the tissue stored in $80-95 \%$ ethanol at $-20{ }^{\circ} \mathrm{C}$.

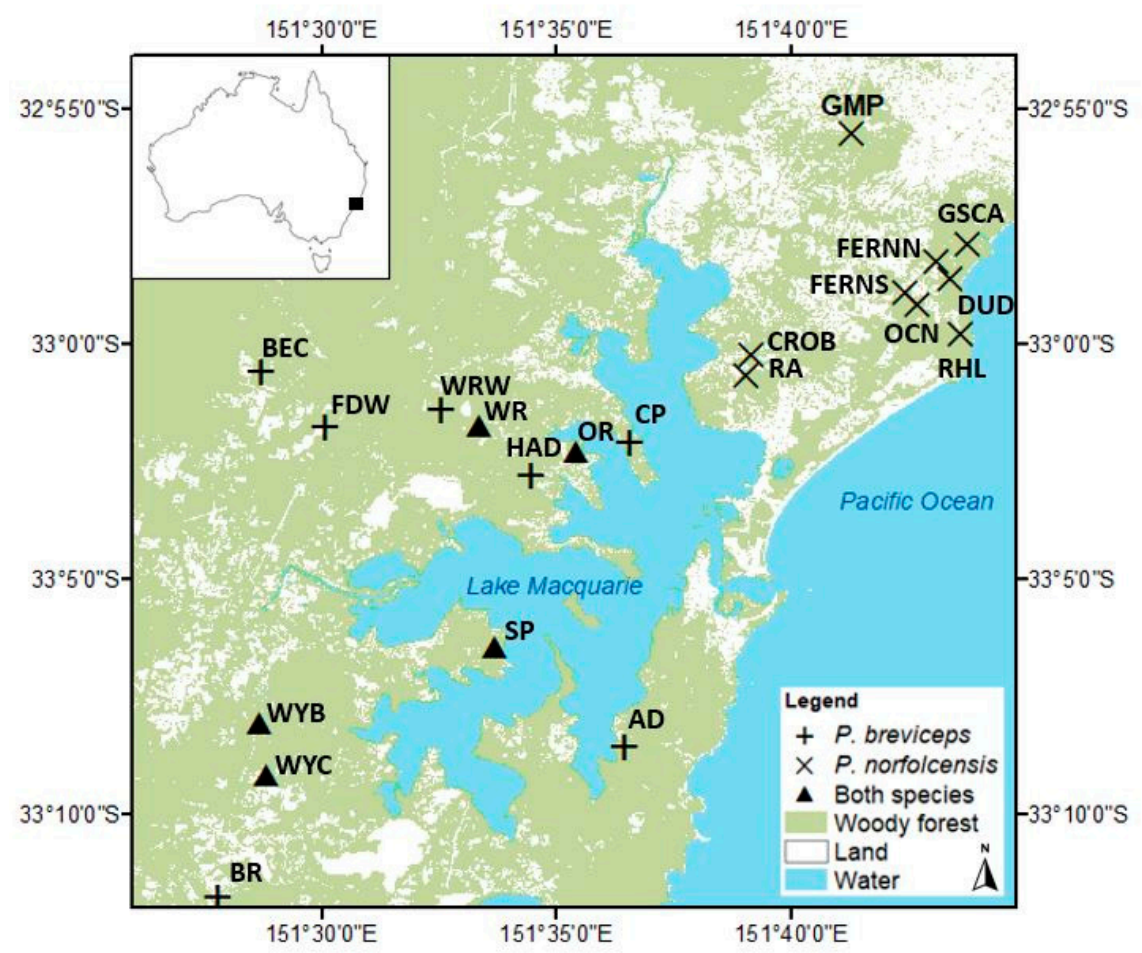

Figure 2. Twenty-one sampling locations of squirrel gliders (P. norfolcensis) and sugar gliders (P. breviceps) in the Lake Macquarie Local Government Area (NSW, Australia). The map shows locations where both species were present during the trapping period (triangles). The location of the potential hybrid is labelled "GMP". $n=179$. 


\subsection{Sequencing Mitochondrial DNA}

Genomic DNA was extracted from 179 Petaurus ear tissue samples using the One4-ALL Genomic Miniprep Kit (BioBasic Inc., Markham, ON, Canada) and DNeasy Blood and Tissue Kit (Qiagen, Hilden, Germany) as per the manufacturer's instructions. If the identification to species remained uncertain despite morphological measurements, the mitochondrial (mtDNA) cytochrome b gene was sequenced using primer pair L14724 and H15149 following the instructions by Kocher et al. [26] and Irwin et al. [27]. This gene was chosen as it is the most sequenced mtDNA gene for Petaurus species, and therefore, there are numerous accessions available on GenBank in which to compare them [28]. PCR and post-PCR treatment methods were those of Knipler et al. [25]. Sequencing was undertaken using a 3130xl Genetic Analyzer (Applied Biosystems Pty Ltd., Scoresby, VIC, Australia). A total of 385 base pair sequences were edited and aligned with ChromasPro v 1.33 (Technelysium Pty Ltd., Brisbane, QLD, Australia) and BioEdit v 7.2.6.1 [29]. MtDNA cytochrome $\mathrm{b}$ sequences were then compared to $P$. $b$. breviceps and $P$. norfolcensis cytochrome b sequences through a BLASTN search of GenBank.

\subsection{Next-Generation Sequencing}

While morphology and mtDNA helped assign individuals to a species, they could not ascertain whether any individuals were $P$. $b$. breviceps $\times$ P. norfolcensis hybrids. At this point, the advent of next-generation sequencing and SNPs allowed important further analysis to occur. The remaining genomic DNA from the 179 glider individuals were sent to Diversity Arrays Technology, Canberra, Australia (DArTseq). DArTseq uses genome-complexity reduction methods to obtain thousands of genome-wide SNPs with restriction enzymes and next-generation sequencing technology. Additionally, DArTseq SNP data have been used to efficiently detect hybrids in frogs (Litoria ewingii $\times$ L. paraewingi) and clades of lizards (Ctenophorus caudicinctus) [8]. In our Petaurus study, DArTseq chose PstI-SphI restriction enzymes for optimal DNA fragmentation. Digestion and ligation followed that of Kilian et al. [30] with the addition of compatible adaptors for the PstI-SphI restriction enzymes. PCR fragments were amplified under the following conditions: denaturation of $94{ }^{\circ} \mathrm{C}$ for $1 \mathrm{~min}$, followed by 30 cycles of denaturation $\left(94^{\circ} \mathrm{C}\right.$ for $\left.20 \mathrm{~s}\right)$, annealing $\left(58^{\circ} \mathrm{C}\right.$ for $30 \mathrm{~s})$ and extension $\left(72{ }^{\circ} \mathrm{C}\right.$ for $\left.45 \mathrm{~s}\right)$ steps, and a final 7 -min extension step at $72{ }^{\circ} \mathrm{C}$. Amplified products were then equimolarly combined and subjected to a c-Bot bridge PCR and sequenced on an Illumina Hiseq2500 for 77 cycles.

DArTseq used their analytical pipelines to process the sequences and assign them to individual glider samples. Sequences were aligned to the Leadbeaters possum (Gymnobelideus leadbeateri) reference genome and markers were called with an average read depth of 20 reads per locus and a minimum sequence identity of $70 \%$. After obtaining the data from DArTseq, the SNPs were filtered further using the dart $R$ 1.1.11 package in $\mathrm{R}$ 4.0.2 [31,32]. Loci with $>5 \%$ missing values were removed, loci with reproducibility $<0.99$ were removed, and those where hamming distance was $<0.2$. Any linked or monomorphic loci were also removed as well as those that deviated from the Hardy-Weinberg equilibrium. The remaining dataset was used for genomic analyses.

\subsection{Statistical Analyses}

We first ran a principal coordinates analysis (PCoA) in R 4.0.2 [32] to visualise the genetic distances and dissimilarities between individuals. A screeplot detected the number of PC axes that displayed most of the variation and these axes were plotted to examine the genetic differences between the two Petaurus species. Outlier individuals were flagged as potential hybrids. Pairwise $\mathrm{F}_{\mathrm{ST}}$ calculated the genetic distances of species and potential hybrids using the StAMPP v1.6.1 package in $\mathrm{R}$ and 10,000 bootstraps. This package uses methods by Weir and Cockerham [33] and Wright [34]. Next, observed and expected heterozygosities were calculated for $P$. $b$. breviceps, $P$. norfolcensis, and potential hybrids with the dart $R$ and adegenet 2.1.3 package in $R[31,35]$. Hybrids typically have high levels of heterozygosity (and reduced fitness) as their alleles come from different species [36], so 
these values were compared to see if there were high levels of heterozygosity in potential hybrid glider samples.

Both STRUCTURE and NewHybrids analyses have been used to identify hybrids in mammal research including Felix catus $\times$ F. silvestris [37,38], Damaliscus pygargus pygargus $\times$ D. p. phillipsi [39], and Odocoileus hemionus hemionus $\times$ O. h. columbianus [40]. STRUCTURE uses Bayesian clustering and Markov Chain Monte Carlo estimation to assign individuals to a group (predefined clusters, " $\mathrm{K}$ ") based on their allele frequencies [41]. Here, the SNP dataset was run through STRUCTURE v2.3.4 to assign glider individuals to genetic clusters (species) and identify potential hybrids based on admixture [42]. K values one to 15 were run eight times each with a 10,000-length burn-in period and 10,000 Monte Carlo Markov Chain replications. The optimal number of clusters $(\mathrm{K})$ was then chosen using the Evanno method in STRUCTURE Harvester (Web v0.6.94) [43,44]. Individuals were considered pure to a cluster if the $Q$ value was greater than 0.9 as per Wyk et al. [39], and subsequently considered admixed if $0.1<\mathrm{Q}<0.9$.

NewHybrids v1.0 uses a quantitative approach to identify hybrid individuals [45]. NewHybrids uses genotype frequencies to calculate the posterior probability that each Petaurus individual falls into the following categories: pure $P$. norfolcensis, pure $P$. $b$. breviceps, first generation hybrid (F1), second generation hybrid (F2), backcross to $P$. b. breviceps (0_Bx), and backcross to P. norfolcensis (1_Bx) (Table 1). The program only accepts 200 loci, so these were subsampled at random using the "gl2nhyb" function in the dartR package. A total of 10,000 sweeps were used for the burn-in and 10,000 sweeps were used for the Monte Carlo averages. Results for both STRUCTURE and NewHybrids were plotted in R.

Table 1. NewHybrids genotype frequency classes tested with 200 loci.

\begin{tabular}{cccccc}
\hline \multirow{2}{*}{$\begin{array}{c}\text { Genotype Frequency } \\
\text { Classes }\end{array}$} & Product of & \multicolumn{4}{c}{ Expected Genotype Frequencies } \\
\cline { 3 - 5 } & $2 \times$ P. b. breviceps & 1.00 & 0.00 & 0.00 & 0.00 \\
\hline Pure P. b. breviceps & $2 \times$ P. norfolcensis & 0.00 & 0.00 & 0.00 & 1.00 \\
\hline Pure P. norfolcensis & F1 $\times$ F1 & 0.00 & 0.50 & 0.50 & 0.00 \\
\hline $\begin{array}{c}\text { First generation } \\
\text { hybrid (F1) }\end{array}$ & $\begin{array}{c}\text { P. b. breviceps } \times P . \\
\text { norfolcensis }\end{array}$ & 0.25 & 0.25 & 0.25 & 0.25 \\
\hline $\begin{array}{c}\text { Second generation } \\
\text { hybrid (F2) }\end{array}$ & F1 $\times$ P. b. breviceps & 0.50 & 0.25 & 0.25 & 0.00 \\
\hline $\begin{array}{c}P . \text { b. breviceps } \\
\text { backcross (0_Bx) }\end{array}$ & $\mathrm{F} 1 \times$ P. norfolcensis & 0.00 & 0.25 & 0.25 & 0.50 \\
\hline $\begin{array}{c}\text { P. norfolcensis } \\
\text { backcross (1_Bx) }\end{array}$ & & & & \\
\hline
\end{tabular}

\section{Results}

\subsection{Morphological Features}

Ninety-one individuals were identified as $P . b$. breviceps and 87 individuals were identified as $P$. norfolcensis based on morphological data. One individual (individual "GMP24") was recorded as an adult male because of the large testes and active scent glands. It was initially believed to be $P$. norfolcensis because all previous captures at the site had been $P$. norfolcensis and its tail tip colour, head width, and head length measurements aligned with morphological features of the species (Figure 3). Despite this assumption, the sample was flagged for DNA species confirmation because the weight of the individual was $170 \mathrm{~g}$ and thus heavier than the average adult male $P . b$. breviceps $(123.53 \mathrm{~g})$ but lighter than the average adult P. norfolcensis ( $214.91 \mathrm{~g}$ ) (Figure 3). No photographs were taken of the individual. 

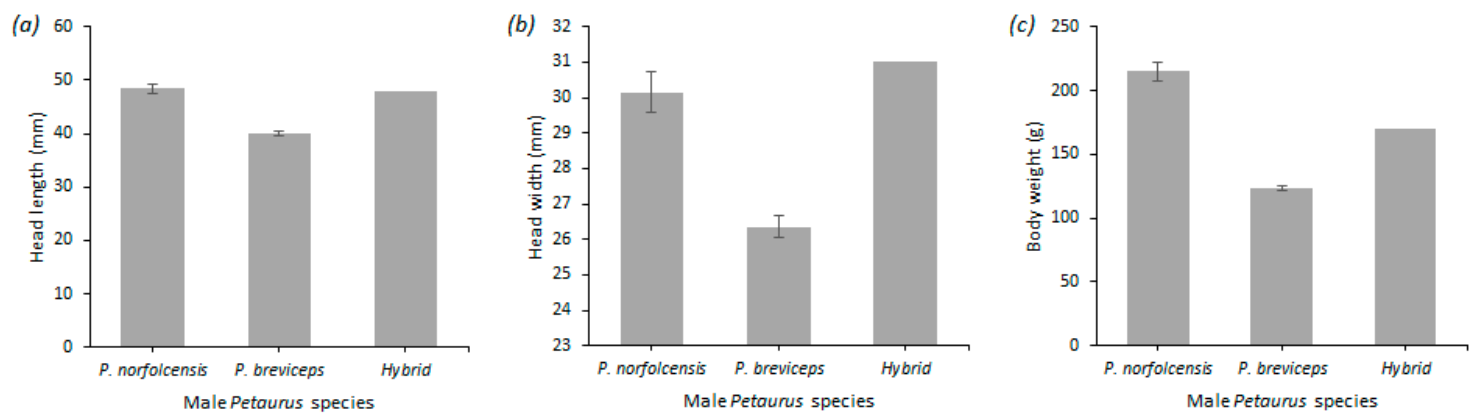

Figure 3. Mean morphological measurements of 23 male adult squirrel gliders (P. norfolcensis) and 47 male adult sugar gliders (P. breviceps) \pm standard error. Morphological measurements of the hybrid (P. breviceps $\times$ P. norfolcensis $)$ are also included. Measurements include (a) average head length of male Petaurus species in millimetres, (b) head width of male Petaurus species in millimetres, and (c) body weight of male Petaurus species in grams.

\subsection{Mitochondrial DNA Sequence}

As the species identity of individual GMP24 remained uncertain, its cytochrome $b$ sequence was run through the BLASTN function on GenBank. The search returned a $100 \%$ identity match to a cytochrome $\mathrm{b}$ sequence of a P. b. breviceps sampled from Western Sydney, NSW, uploaded by Pavlova et al. [28] (Sequence ID FJ657662.1). The cytochrome $\mathrm{b}$ sequences of all other individuals matched the species that was identified through morphology.

\subsection{Genome Wide SNPs: Testing for Hybrid}

A total of 36,617 SNPs were obtained from DArTseq. After filtering, 10,111 SNPs remained from 179 Petaurus individuals and this dataset was used for the subsequent analyses. AMOVA results found that $76.340 \%$ of the genetic variation was apportioned between groups (P. b. breviceps, P. norfolcensis, and potential hybrid), $2.611 \%$ of the variation was apportioned between samples within groups, and $21.049 \%$ of the variation was apportioned between samples. The PCoA plot showed clear separation of the two Petaurus species on the first axis, with the PCoA Axis 1 accounting for a large proportion of the genetic variation (73.8\%) and the PCoA Axis 2 accounting for only $1.1 \%$ of the genetic variation in the dataset (Figure 4). The PCoA Axis 2 showed greater variation for P. norfolcensis than for P. b. breviceps. When comparing the two species, the potential hybrid ("GMP24") more closely resembled the nuclear DNA profile of P. norfolcensis (Figure 4), even though its mtDNA sequence matched that of $P . b$. breviceps. The pairwise genetic distances of species also conveyed this as $P$. norfolcensis had a smaller genetic distance to the potential hybrid than P. b. breviceps $\left(\mathrm{F}_{\mathrm{ST}}=0.346\right.$ vs. 0.671$)$ (Table 2$)$.

Table 2. Pairwise FST of P. b. breviceps, P. norfolcensis, and potential hybrid (individual GMP24) are shown below the diagonal, while significance is shown above the diagonal. ${ }^{*}=$ significant $(p<0.05)$, NS $=$ not significant $(p>0.05)$.

\begin{tabular}{cccc}
\hline Species & $\boldsymbol{P .}$. . breviceps & P. norfolcensis & Hybrid \\
\hline P. b. breviceps & - & $*$ & $*$ \\
P. norfolcensis & 0.767 & - & $*$ \\
Hybrid & 0.671 & 0.346 & - \\
\hline
\end{tabular}




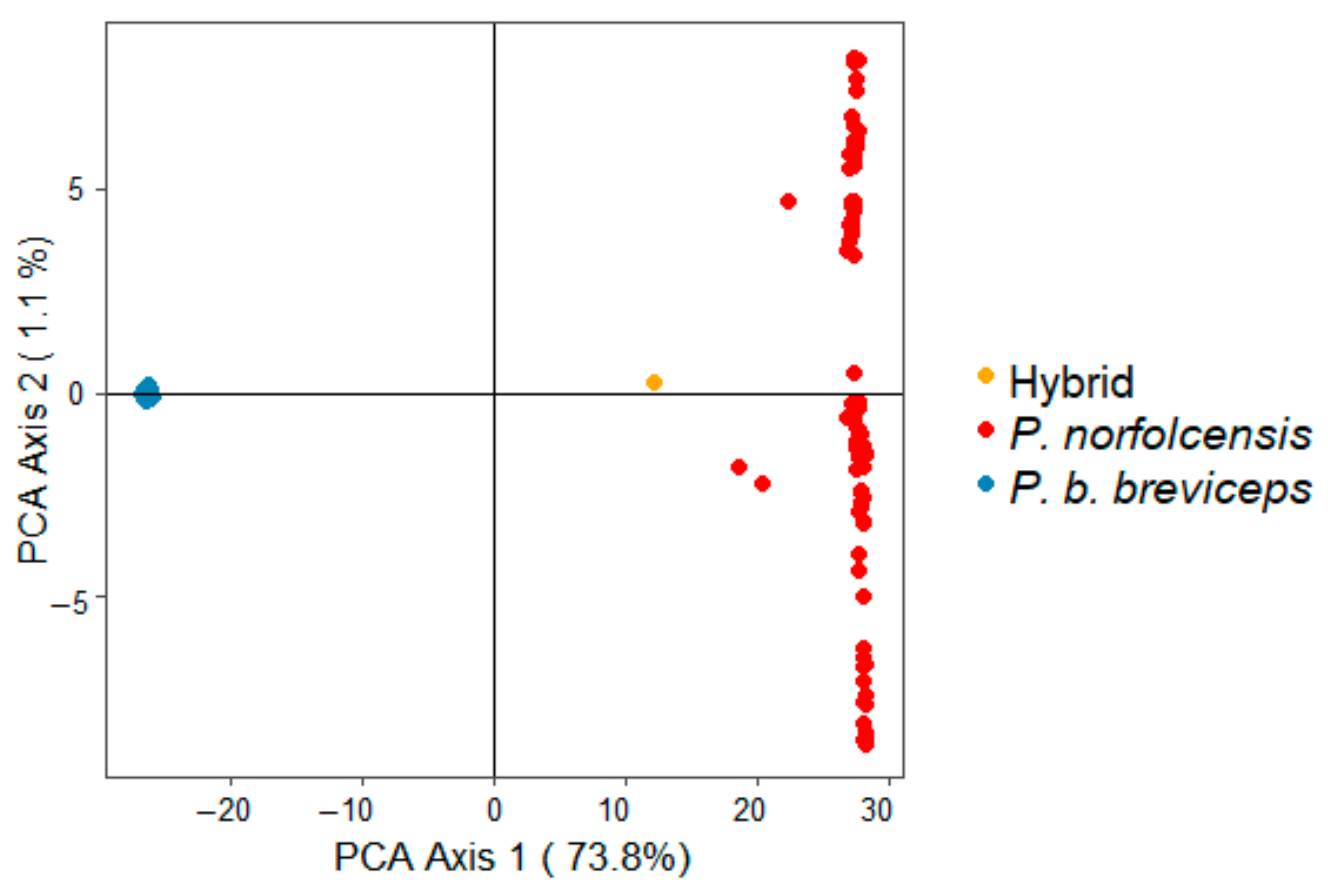

Figure 4. Principle coordinate analysis (PCoA) from genetic distances of 10,111 SNPs belonging to squirrel gliders (P. norfolcensis, $n=87$ ) and sugar gliders $(P . b$. breviceps, $n=91)$. The potential hybrid individual $(P . b$. breviceps $\times$ P. norfolcensis $)$ is coloured purple.

The average observed heterozygosity of $P . b$. breviceps and P. norfolcensis were similar to their expected heterozygosity values, however, the observed heterozygosity of the potential hybrid (GMP24) was higher than its expected heterozygosity as well as the observed heterozygosity of the two Petaurus species (potential hybrid $\mathrm{Ho}=0.220, \mathrm{Hs}=0.114$ ) (Table 3).

Table 3. Expected (Hs) and observed heterozygosity (Ho) of the two Petaurus species and the potential hybrid (individual GMP24).

\begin{tabular}{ccc}
\hline Species & Hs & Ho \\
\hline P. $b$. breviceps & 0.084 & 0.082 \\
P. norfolcensis & 0.092 & 0.096 \\
Hybrid & 0.114 & 0.220 \\
\hline
\end{tabular}

Both STRUCTURE and NewHybrids identified individual GMP24 as an admixed, hybrid individual. The STRUCTURE analysis detected the most likely number of clusters to be $\mathrm{K}=2$, indicative of the two glider species P. b. breviceps and P. norfolcensis (Figure 5). Ninety-one gliders were assigned pure to cluster K1 (P. norfolcensis), 87 gliders were assigned pure to cluster $\mathrm{K} 2$ (P. b. breviceps), and one individual (GMP24) was admixed with clusters K1 and K2 $\left(\mathrm{Q}_{\mathrm{K} 1}=0.709, \mathrm{Q}_{\mathrm{K} 2}=0.291\right)$ (Figure 6). Similarly, NewHybrids assigned 91 gliders as pure $P$. norfolcensis, 87 gliders as pure $P$. b. breviceps, and one individual (GMP24) as a P. norfolcensis backcross (Table 1 and Figure 7). These assignments match the morphological assessments that were made in the field and suggest that individual GMP24 is a hybrid P. norfolcensis backcross. There was no evidence of F1 or F2 hybrids in the dataset. 


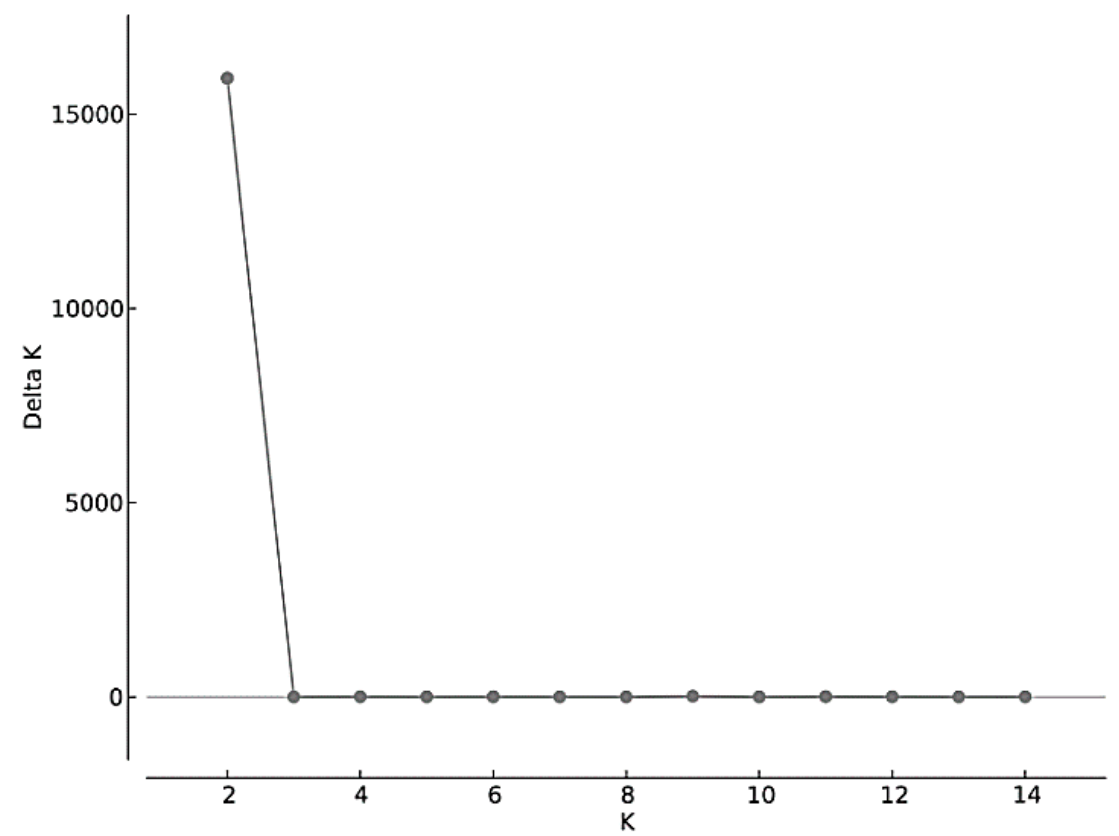

Figure 5. Delta K results from the Structure Harvester Evanno method. STRUCTURE tested 15 clusters $(K=1-15)$ with eight replicates each using 10,111 SNPs and 179 Petaurus individuals. Two clusters were detected $(K=2)$ using DeltaK = mean $\left(\left|L^{\prime \prime}(K)\right|\right) / \operatorname{sd}(L(K))$.
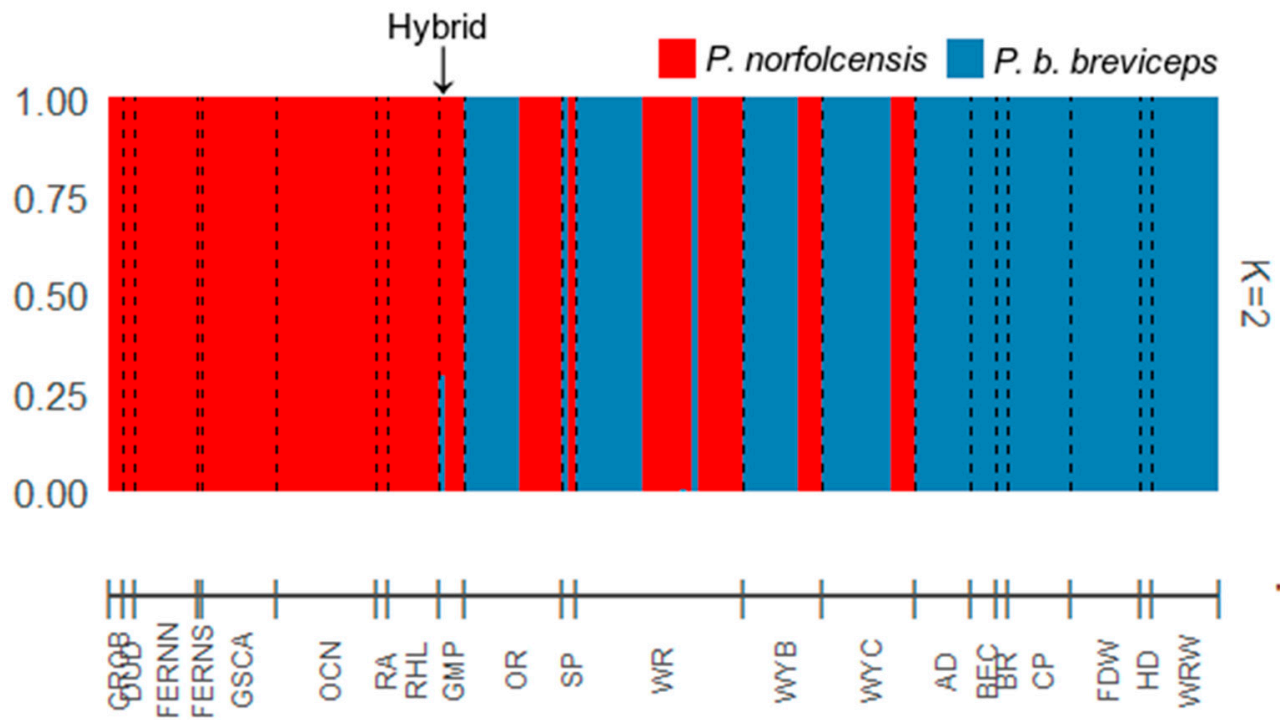

Figure 6. STRUCTURE admixture results using $K=2$ and 10,111 SNPs. A total of 178 of the 179 Petaurus individuals were assigned "pure" to a cluster (P. norfolcensis or P. b. breviceps species), with one individual displaying admixture (hybrid P. norfolcensis $\times P$. b. breviceps). Locations are listed along the bar on the $x$ axis (refer to Figure 2 for more information). 


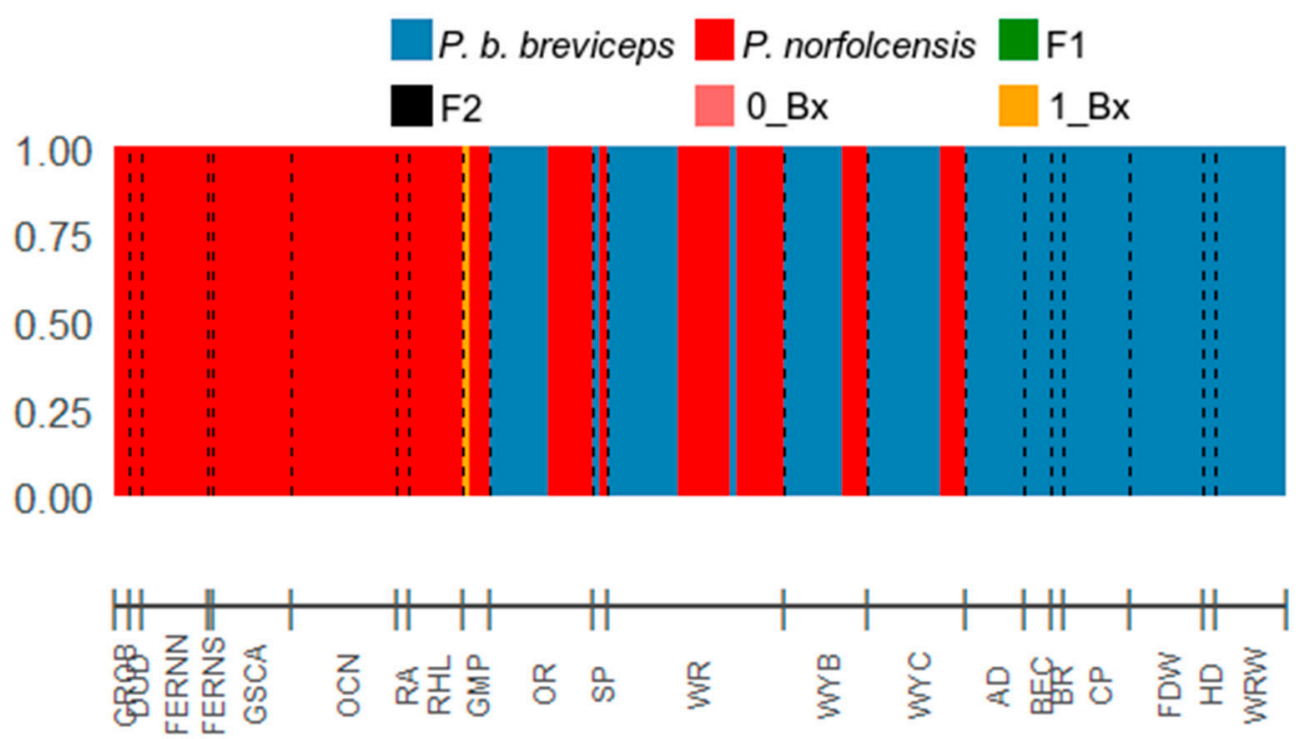

Figure 7. Results of NEWHYBRIDS analysis to identify hybrids between Petaurus species using 10,111 SNPs $(n=179)$. Possible results include pure squirrel glider (P. norfolcensis), pure sugar glider (P. b. breviceps), first generation hybrid (F1), second generation hybrid (F2), backcross to $P$. $b$. breviceps (0_Bx), and backcross to P. norfolcensis (1_Bx). Locations are listed along the bar on the $x$ axis (refer to Figure 2 for more information). $y$-axis indicates assignment probability.

\section{Discussion}

Prior to this study, there were no known cases of Petaurus hybridisation in the wild. Our study detected one hybrid individual in the Hunter region of NSW where the $P . b$. breviceps and P. norfolcensis distribution overlaps. The NewHybrids analysis detected a $P$. norfolcensis backcross, a very significant and valuable discovery as it signifies that a $P . b$. breviceps $\times$ P. norfolcensis $\mathrm{F} 1$ hybrid was fertile and able to reproduce with a P. norfolcensis. Additionally, we determined that the initial interspecies pairing was a female $P . b$. breviceps and a male $P$. norfolcensis due to the sequence of the maternally inherited cytochrome $b$ gene. This F1 individual was determined to have been female in order to have passed on the $P$. b. breviceps mtDNA gene sequence to its offspring; the P. norfolcensis backcross. This exact combination has been reported in captivity by Fleay [2], who reported that a female P. b. breviceps from Victoria and a male P. norfolcensis from Queensland bred in captivity and produced a female offspring. Their offspring was fertile and reproduced with its $P$. norfolcensis father, which is supported by the findings of our study. This is significant as it means that hybrids are contributing to the gene pool of both P. b. breviceps and P. norfolcensis species in the location where it was trapped.

Our study detected backcrosses but did not detect F1 hybrids, resembling Canid research by Dufresnes et al. [46] and Macropus research by Neaves et al. [47]. Neaves et al. [47] investigated the marsupial hybridisation of Macropus fuliginosus and Macropus giganteus. They found no evidence of F1 hybrids, but a significant percentage of backcrosses. The findings by Neaves et al. [47] suggest that it is more common to encounter a backcross hybrid than an F1 hybrid in the wild, as it only takes one rare F1 hybrid to produce multiple backcrosses in their lifetime [47,48].

The location where the Petaurus hybrid was trapped is surrounded by urban development and heavily used roads, with the average daily traffic count in 2018 being 42,262 vehicles [49]. During our research, only P. norfolcensis were caught at this location during the trapping period $(n=3)$. Yadav et al. [50] discuss possible reasons for species hybridisation in the wild including small population size and habitat fragmentation. It is possible that both Petaurus species that occur at this site are in such low densities or sex ratios that they are forced to interact and mate with each other. Urbanisation and habitat 
fragmentation at this location is likely making it difficult for the species to disperse [50,51]. Increasing habitat connectivity in this area is essential.

While this study demonstrates evidence of fertile hybrids, it is important to note that there is currently no evidence of a female $P$. norfolcensis successfully producing a hybrid with a male $P$. $b$. breviceps, and there is no evidence of any pairings producing a fertile male F1 hybrid in captivity or in the wild. Haldane's rule states that "when in the offspring of two different animal races one sex is absent, rare, or sterile, that sex is the heterozygous sex" [52]. Schilthuizen et al. [53] found 39 mammal species that obeyed this rule where male hybrids displayed sterility $(n=34)$ or inviability $(n=5)$. One example by Borodin et al. [54] examined F1 hybrids of Thrichomys pachyurus, T. apereoides apereoides, and T. apereoides laurentius, and found that all F1 males were sterile while only some F1 females were sterile. It is possible that the Petaurus genus also obeys this rule, as there is currently only evidence to support fertile female hybrids. If this holds true, then it is possible that the male P. norfolcensis backcross (individual GMP24) is sterile like other male backcrosses [50] and does not contribute to the population where it was sampled.

Hybrid glider individuals were predicted to have high levels of heterozygosity due to outbreeding between two separate species, resulting in a reduction in fitness [36]. As expected, higher heterozygosity was observed in the hybrid Petaurus individual (GMP24) when compared to the purebred Petaurus species. This is comparable to research on Podarcis muralis [55], Canis lupis [56], and Zonotrichia leucophrys subspecies [57]. Despite this, only one hybrid was identified in our study, so our results do not suggest that hybridisation is having a negative effect on the genetic structure or diversity of the $P . b$. breviceps or P. norfolcensis populations in the Hunter region. It does, however, suggest that the location in question needs added connectivity to surrounding habitat fragments to negate effects of small population sizes and habitat patch isolation. Despite only detecting one backcross hybrid, the results of this study are extremely important as $P$. b. breviceps and P. norfolcensis co-occur along the east coast of Australia and breed simultaneously. We have shown that they have the capability to hybridise in the wild, and there may be other cases of hybridisation where they coexist in low densities.

\section{Conclusions}

In conclusion, our study is the first to detect hybridisation of Petaurus species in the wild. Analyses of the genome-wide SNPs proved to be the most reliable way to identify hybrids, however, it is equally important to report morphological measurements and mtDNA sequences to gain insight into the fertility status of the hybrid individuals. Hybridisation must be considered in small, isolated habitat patches where both Petaurus species occur in low densities, especially if male hybrids prove to be sterile and take resources from other fertile individuals.

Author Contributions: Conceptualization, K.M.M. and M.D.; methodology, K.M.M., M.D. and M.L.K.; software, K.M.M., M.D. and M.L.K.; validation, K.M.M., M.D. and M.L.K.; formal analysis, M.L.K.; investigation, M.L.K.; resources, K.M.M., M.D. and M.L.K.; data curation, M.L.K.; writing—original draft preparation, M.L.K.; writing—review and editing, K.M.M., M.D. and M.L.K.; visualization, M.L.K.; supervision, K.M.M. and M.D.; project administration, K.M.M. and M.D.; funding acquisition, K.M.M. and M.L.K. All authors have read and agreed to the published version of the manuscript.

Funding: This research was funded by Lake Macquarie City Council (Environmental Grants 20182020) and the University of Wollongong, Centre for Sustainable Ecosystem Solutions (Research Student Support Grant 2020).

Institutional Review Board Statement: Genetic samples were collected under University of Wollongong Animal Ethics permit AE15/11 and AE19/02, with NSW Scientific License SL101587 and SL101968. Additional samples were donated by the University of Newcastle, collected under their Animal Care and Ethics Committee (A-2015-510) and NSW Scientific License SL100190.

Informed Consent Statement: Not applicable. 
Data Availability Statement: Data are available from the authors upon request.

Acknowledgments: The authors would like to acknowledge the Awabakal people, the Traditional Custodians of the land where our research took place. We would like to thank Lake Macquarie City Council and NSW National Parks and Wildlife Service for their assistance. Finally, we would like to extend special thanks to those who assisted in collecting samples; particularly Reannan Honey, Ninon Meyer, and John Clulow.

Conflicts of Interest: The authors declare no competing interest. The funders had no role in the design of the study; in the collection, analyses, or interpretation of data; in the writing of the manuscript, or in the decision to publish the results.

\section{References}

1. Fox, B.; Murray, J. Laboratory hybridization of Australian Rattus fuscipes and Rattus lutreolus and its karyotypic confirmation. Aust. J. Zool. 1979, 27, 691-698. [CrossRef]

2. Fleay, D. Gliders of the Gum Trees: The Most Beautiful and Enchanting Australian Marsupials; The Hawthorn Press: Hawthorn, VIC, Australia, 1947.

3. Zuckerman, S. The breeding seasons of mammals in captivity. Proc. Zool. Soc. Lond. 1952, 122, 827-950. [CrossRef]

4. Twyford, A.D.; Ennos, R.A. Next-generation hybridization and introgression. Heredity 2012, 108, 179-189. [CrossRef] [PubMed]

5. Harrison, R.G.; Larson, E.L. Hybridization, Introgression, and the Nature of Species Boundaries. J. Hered. 2014, 105, 795-809. [CrossRef] [PubMed]

6. Mattucci, F.; Galaverni, M.; Lyons, L.A.; Alves, P.C.; Randi, E.; Velli, E.; Pagani, L.; Caniglia, R. Genomic approaches to identify hybrids and estimate admixture times in European wildcat populations. Sci. Rep. 2019, 9, 11612. [CrossRef]

7. Cairns, K.M.; Shannon, L.M.; Koler-Matznick, J.; Ballard, J.W.O.; Boyko, A.R. Elucidating biogeographical patterns in Australian native canids using genome wide SNPs. PLoS ONE 2018, 13, e0198754. [CrossRef]

8. Melville, J.; Haines, M.L.; Boysen, K.; Hodkinson, L.; Kilian, A.; Smith Date, K.L.; Potvin, D.A.; Parris, K.M. Identifying hybridization and admixture using SNPs: Application of the DArTseq platform in phylogeographic research on vertebrates. $R$. Soc. Open Sci. 2017, 4, 161061. [CrossRef]

9. Levin, D. Hybridization and Extinction: In protecting rare species, conservationists should consider the dangers of interbreeding, which compound the more well-known threats to wildlife on JSTOR. Am. Sci. 2002, 90, 254-261. [CrossRef]

10. Shurtliff, Q.R. Mammalian hybrid zones: A review. Mamm. Rev. 2013, 43, 1-21. [CrossRef]

11. Turner, L.M.; White, M.A.; Tautz, D.; Payseur, B.A. Genomic Networks of Hybrid Sterility. PLoS Genet. 2014, 10, e1004162. [CrossRef]

12. Simberloff, D. Hybridization between native and introduced wildlife species: Importance for conservation. Wildl. Biol. 1996, 2, 143-150. [CrossRef]

13. Wintle, B.; Bekessy, S. Let's Get this Straight, Habitat Loss is the Number-One Threat to Australia's Species. Available online: http:/ / theconversation.com/lets-get-this-straight-habitat-loss-is-the-number-one-threat-to-australias-species-85674 (accessed on 26 March 2018).

14. Woinarski, J.C.Z.; Burbidge, A.; Harrison, P.L. The Action Plan for Australian Mammals 2012; CSIRO Publishing: Collingwood, VIC, Australia, 2014; ISBN 9780643108738.

15. Cremona, T.; Baker, A.M.; Cooper, S.J.B.; Montague-Drake, R.; Stobo-Wilson, A.M.; Carthew, S.M. Integrative taxonomic investigation of Petaurus breviceps (Marsupialia: Petauridae) reveals three distinct species. Zool. J. Linn. Soc. 2020, 191, 503-527. [CrossRef]

16. Crane, M.; Lindenmayer, D.B.; Banks, S.C. Conserving and restoring endangered southern populations of the Squirrel Glider (Petaurus norfolcensis) in agricultural landscapes. Ecol. Manag. Restor. 2017, 18, 15-25. [CrossRef]

17. Malekian, M.; Cooper, S.J.B.; Norman, J.A.; Christidis, L.; Carthew, S.M. Molecular systematics and evolutionary origins of the genus Petaurus (Marsupialia: Petauridae) in Australia and New Guinea. Mol. Phylogenet. Evol. 2010, 54, 122-135. [CrossRef]

18. NSW Scientific Committee. NSW Scientific Committee established under the Threatened Species Conservation Act 1995 Squirrel Glider Petaurus Norfolcensis Review of Current Information in NSW. 2008. Available online: https: //www.environment.nsw.gov.au/-/media/OEH/Corporate-Site/Documents/Animals-and-plants/Scientific-Committee/scsquirrel-glider-petaurus-norfolcensis-review-report.pdf?la=en\&hash=63FC3FA938DBA28BC42FA33AAFB9D5AF321E166E (accessed on 15 July 2021).

19. Suckling, G.C. Population ecology of the sugar glider, Petaurus breviceps, in a system of fragmented habitats. Wildl. Res. 1984, 11, 49-75. [CrossRef]

20. Lindenmayer, D. Gliders of Australia: A Natural History; UNSW Press: Sydney, NSW, Australia, 2002; ISBN 086840523X.

21. Smith, M.J. Observations on Growth of Petaurus Breviceps and P. Novfolcensis (Petauridae: Marsupialia) in Captivity. Wildl. Res. 1979, 6, 141-150. [CrossRef]

22. Quin, D.G. Population ecology of the squirrel glider (Petaurus norfolcensis) and the sugar glider (P. breviceps) (Maruspialia: Petauridae) at Limeburners Creek, on the central north coast of New South Wales. Wildl. Res. 1995, 22, 471-505. [CrossRef] 
23. Smith, A.P. Diet and Feeding Strategies of the Marsupial Sugar Glider in Temperate Australia. J. Anim. Ecol. 1982, 51, 149. [CrossRef]

24. Ball, T.; Adams, E.; Goldingay, R.L. Diet of the squirrel glider in a fragmented landscape near Mackay, central Queensland. Aust. J. Zool. 2009, 57, 295-304. [CrossRef]

25. Knipler, M.; Dowton, M.; Clulow, J.; Meyer, N.; Mikac, K.M. Genome-wide SNPs Detect Fine-scale Genetic Structure in Threatened Populations of Squirrel Glider Petaurus norfolcensis. Res. Sq. 2021. under review. [CrossRef]

26. Kocher, T.D.; Thomas, W.K.; Meyer, A.; Edwards, S.V.; Paabo, S.; Villablanca, F.X.; Wilson, A.C.; Pääbo, S.; Villablanca, F.X.; Wilson, A.C. Dynamics of mitochondrial DNA evolution in animals: Amplification and sequencing with conserved primers. Proc. Natl. Acad. Sci. USA 1989, 86, 6196-6200. [CrossRef]

27. Irwin, D.M.; Kocher, T.D.; Wilson, A.C. Evolution of the cytochrome b gene of mammals. J. Mol. Evol. 1991, 32, 128-144. [CrossRef] [PubMed]

28. Pavlova, A.; Walker, F.M.; Van der Ree, R.; Cesarini, S.; Taylor, A.C. Threatened populations of the Australian squirrel glider (Petaurus norfolcensis) show evidence of evolutionary distinctiveness on a Late Pleistocene timescale. Conserv. Genet. 2010, 11, 2393-2407. [CrossRef]

29. Hall, T.A. BioEdit: A user-friendly biological sequence alignment editor and analysis program for Windows 95/98/NT. Nucleic Acids Symp. Ser. 1999, 41, 95-98.

30. Kilian, A.; Wenzl, P.; Huttner, E.; Carling, J.; Xia, L.; Blois, H.; Caig, V.; Heller-Uszynska, K.; Jaccoud, D.; Hopper, C.; et al. Diversity arrays technology: A generic genome profiling technology on open platforms. Methods Mol. Biol. 2012, 888, 67-89. [CrossRef] [PubMed]

31. Gruber, B.; Unmack, P.J.; Berry, O.F.; Georges, A. Dartr: An r package to facilitate analysis of SNP data generated from reduced representation genome sequencing. Mol. Ecol. Resour. 2018, 18, 691-699. [CrossRef]

32. R Core Team. R: A Language and Environment for Statistical Computing. Available online: https://www.gbif.org/tool/81287/ra-language-and-environment-for-statistical-computing (accessed on 1 April 2021).

33. Weir, B.S.; Cockerham, C.C. Estimating F-Statistics for the Analysis of Population Structure. Evolution 1984, 38, 1358. [CrossRef] [PubMed]

34. Wright, S. THE Genetical structure of populations. Ann. Eugen. 1949, 15, 323-354. [CrossRef]

35. Jombart, T. Adegenet: A R package for the multivariate analysis of genetic markers. Bioinformatics 2008, 24, 1403-1405. [CrossRef]

36. Moehring, A.J. Heterozygosity and its unexpected correlations with hybrid sterility. Evolution 2011, 65, 2621. [CrossRef]

37. Oliveira, R.; Randi, E.; Mattucci, F.; Kurushima, J.D.; Lyons, L.A.; Alves, P.C. Toward a genome-wide approach for detecting hybrids: Informative SNPs to detect introgression between domestic cats and European wildcats (Felis silvestris). Heredity 2015, 115, 195-205. [CrossRef]

38. Steyer, K.; Tiesmeyer, A.; Muñoz-Fuentes, V.; Nowak, C. Low rates of hybridization between European wildcats and domestic cats in a human-dominated landscape. Ecol. Evol. 2018, 8, 2290-2304. [CrossRef]

39. Van Wyk, A.M.; Dalton, D.L.; Hoban, S.; Bruford, M.W.; Russo, I.-R.M.; Birss, C.; Grobler, P.; van Vuuren, B.J.; Kotzé, A. Quantitative evaluation of hybridization and the impact on biodiversity conservation. Ecol. Evol. 2017, 7, 320-330. [CrossRef]

40. Haines, M.L.; Luikart, G.; Amish, S.J.; Smith, S.; Latch, E.K. Evidence for adaptive introgression of exons across a hybrid swarm in deer. BMC Evol. Biol. 2019, 19, 199. [CrossRef]

41. Porras-Hurtado, L.; Ruiz, Y.; Santos, C.; Phillips, C.; Carracedo, Á.; Lareu, M.V. An overview of STRUCTURE: Applications, parameter settings, and supporting software. Front. Genet. 2013, 4, 98. [CrossRef]

42. Pritchard, J.K.; Stephens, M.; Donnelly, P. Inference of population structure using multilocus genotype data. Genetics 2000, 155, 945-959. [CrossRef]

43. Evanno, G.; Regnaut, S.; Goudet, J. Detecting the number of clusters of individuals using the software structure: A simulation study. Mol. Ecol. 2005, 14, 2611-2620. [CrossRef]

44. Earl, D.A.; VonHoldt, B.M. STRUCTURE HARVESTER: A website and program for visualizing STRUCTURE output and implementing the Evanno method. Conserv. Genet. Resour. 2012, 4, 359-361. [CrossRef]

45. Anderson, E.C.; Thompson, E.A. A model-based method for identifying species hybrids using multilocus genetic data. Genetics 2002, 160, 1217-1229. [CrossRef]

46. Dufresnes, C.; Remollino, N.; Stoffel, C.; Manz, R.; Weber, J.-M.; Fumagalli, L. Two decades of non-invasive genetic monitoring of the grey wolves recolonizing the Alps support very limited dog introgression. Sci. Rep. 2019, 9, 148. [CrossRef]

47. Neaves, L.E.; Zenger, K.R.; Cooper, D.W.; Eldridge, M.D.B. Molecular detection of hybridization between sympatric kangaroo species in south-eastern Australia. Heredity 2010, 104, 502-512. [CrossRef]

48. Goodman, S.J.; Barton, N.H.; Swanson, G.; Abernethy, K.; Pemberton, J.M. Introgression through rare hybridization: A genetic study of a hybrid zone between red and sika deer (genus Cervus) in Argyll, Scotland. Genetics 1999, 152, 355-371. [CrossRef]

49. Transport for NSW Traffic Volume Viewer. Available online: https://roads-waterways.transport.nsw.gov.au/about/corporatepublications / statistics / traffic-volumes / aadt-map/index.html\#/?z=16\&lat=-32.92009726354131\&lon=151.70382561311817 $\& \mathrm{pco}=1 \& \mathrm{pcl}=1 \& \mathrm{sco}=1 \& \mathrm{scl}=1 \& \mathrm{nd}=1 \& \mathrm{v}=0 \& \mathrm{st}=1 \& \mathrm{id}=05204 \& \mathrm{yr}=2018$ (accessed on 16 July 2021).

50. Yadav, A.D.; Sahu, J.D.; Dubey, A.D.; Gadpayle, R.D.; Kiran Barwa, D.; Kashyap, K.; Yadav, A.; Jain, A.; Sahu, J.; Dubey, A.; et al. An overview on species hybridization in animals. Int. J. Fauna Biol. Stud. 2019, 6, 36-42. 
51. Grabenstein, K.C.; Taylor, S.A. Breaking Barriers: Causes, Consequences, and Experimental Utility of Human-Mediated Hybridization. Trends Ecol. Evol. 2018, 33, 198-212. [CrossRef]

52. Haldane, J.B.S. Sex ratio and unisexual sterility in hybrid animals. J. Genet. 1922, 12, 101-109. [CrossRef]

53. Schilthuizen, M.; Giesbers, M.C.W.G.; Beukeboom, L.W. Haldane's rule in the 21st century. Heredity 2011, 107, 95-102. [CrossRef]

54. Borodin, P.; Barreiros-Gomez, S.; Zhelezova, A.; Bonvicino, C.; D'Andrea, P. Reproductive isolation due to the genetic incompatibilities between Thrichomys pachyurus and two subspecies of Thrichomys apereoides (Rodentia, Echimyidae). Genome 2006, 49, 159-167. [CrossRef]

55. Schulte, U.; Veith, M.; Hochkirch, A. Rapid genetic assimilation of native wall lizard populations (Podarcis muralis) through extensive hybridization with introduced lineages. Mol. Ecol. 2012, 21, 4313-4326. [CrossRef]

56. Lucchini, V.; Galov, A. Randi Evidence of genetic distinction and long-term population decline in wolves (Canis lupus) in the Italian Apennines. Mol. Ecol. 2004, 13, 523-536. [CrossRef]

57. Corbin, K.W. Genic Heterozygosity in the White-Crowned Sparrow: A Potential Index to Boundaries between Subspecies. Auk 1981, 98, 669-680. [CrossRef] 